EESTI NSV TEADUSTE AKADEEMIA TOIMETISED, 28. KOIDE KEEMIA. 1979, NR. 1

ИЗВЕСТИЯ АКАДЕМИИ НАУК ЭСТОНСКОИ ССР. ТОМ 28 ХИМИЯ. 1979, №

\title{
О КОРРЕЛЯЦИИ МЕЖДУ СОДЕРЖАНИЕМ ОРГАНИЧЕСКОГО ВЕЩЕСТВА В ГОРЮЧИХ СЛАНЦАХ И СОСТАВОМ н-АЛКАНОВ ИХ БИТУМОИДОВ
}

K. UROV. POLEVKIVIDE ORGAANILISE AINE SISALDUSE JA NENDE BITUMOIDI $n$-ALKAANIDE KOOSTISE VAHELISEST SEOSEST

K. UROV. ON THE CORRELATION BETWEEN THE ORGANIC MATTER CONTENT OF OIL SHALES AND THE COMPOSITION OF $n$-ALKANES OF THEIR BITUMENS

(Представлена О. Эйзеном)

Содержащиеся в экстрагирующейся органическими растворителями части (битумоиде) осадочных пород образным составом. Имеются данные о том, что основными продуцентами $H$-алканов до $\mathrm{C}_{17}$ включительно являются низшие водные организмы [ $\left.{ }^{1}\right]$, тогда как присутствие парафинов $\mathrm{C}_{25}-\mathrm{C}_{35}$ при заметном преобладании соединений с нечетным числом атомов углерода в молекуле свидетельствует об участии терригенного органического материала в формировании каустобиолита [2]. Для бактериальной биопродукции характерно наличие $H$-алканов $\mathrm{C}_{20}-\mathrm{C}_{30}$ с плавным распределением по длине цепи [ ${ }^{3}$. В ходе диагенеза осадка, во-первых, облегчается состав содержащихся в нем парафинов [ $\left.{ }^{4}\right]$, что подтверждено моделированием [5], и, во-вторых, высокое содержание глинистых минералов в породе тормозит процессы преобразования углеводородов битумоида [6]. Однако в целом вопрос о причинах многообразия состава парафинов битумоидов еще далеко не решен.

На рис. 1. приведено установленное в данной работе распределение по длине цепи $\boldsymbol{H}$-алканов, содержащихся в спирто-бензольных экстрактах горючего сланца трех рабочих пластов, кровли и породной прослойки между двумя верхними пластами сланца Кашпирского месторождения. Общего между алканами этих битумоидов мало, несмотря на близость фациальных условий формирования всей промышленной пачки кашпирского сланца и практически полное отсутствие температурного градиента в пределах рассматриваемого разреза. Но если сопоставить содержание характерных для первичной морской биопродукции $\boldsymbol{H}$-алканов $\mathrm{C}_{10}-\mathrm{C}_{17}$ в суммарных алканах с содержанием в породе органического вещества, то ясно намечается взаимозависимость этих величин (рис. 2): по мере обогащения породы органическим веществом отношение $\left(\mathrm{C}_{10}-\mathrm{C}_{17}\right)$ : : $\left(\mathrm{C}_{18}-\mathrm{C}_{30}\right)$ возрастает. Для сравнения на рис. 2 приведены также данные по припятским сланцам Белоруссии (девон) и кукерситу (ордовик) *; как и в случае кашпирского сланца (юра), указанная тенденция сохра-

* Анализ битумоидов кукерсита проводила Р. Пайс, бнтумоидов кровли и породной прослойки Кашпирского месторождения - В. Высоцкая. 


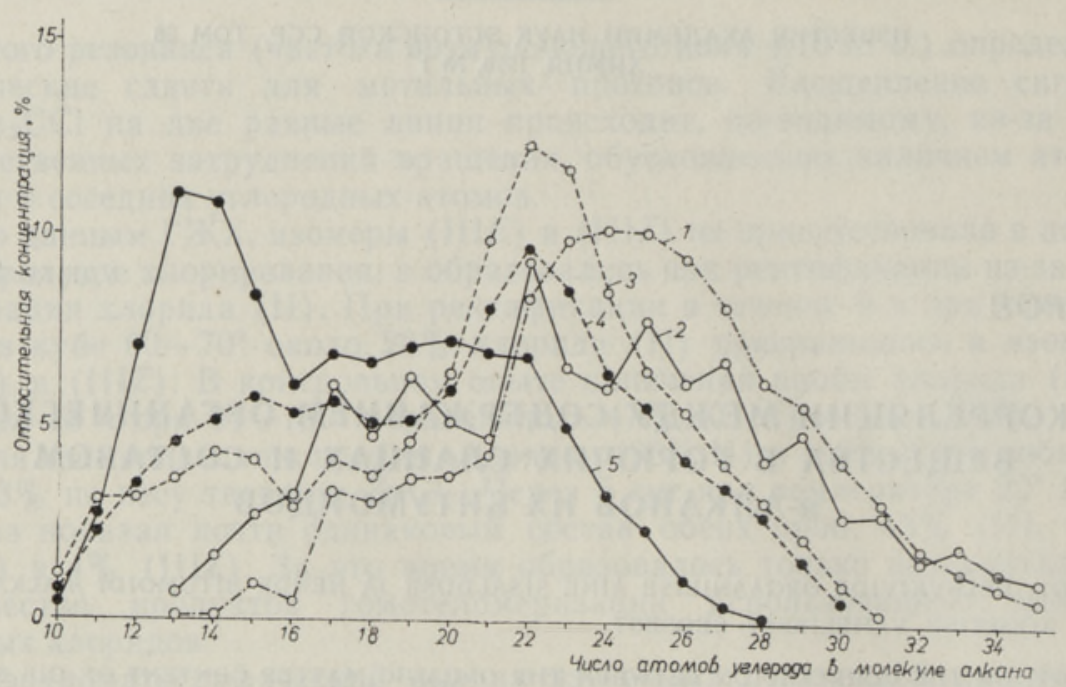

Рис. 1. Распределение $\boldsymbol{H}$-алканов по длине цепи в битумондах пород Қашпирского сланцевого месторождения. 1 - прослойка I/II, 2 - кровля, 3 пласт III, 4 - пласт II, 5 - пласт I.

няется. Возможно, что данная закономерность имеет более общий характер и не ограничивается только горючими сланцами.

Увеличение относительного количества высших парафинов в алкановой фракции битумоидов связано с уменьшением содержания органического вещества в породе и, следовательно, приурочено к пернодам спада жизнедеятельности в водоеме. При этом роль автотрофных водных организмов в формировании керогена действительно должна уменьшиться, а вклад терригенного органического материала и продуктов жизнедеятельности бактерий возрасти. Так, в случае бедной органическим веществом породы кровли кашпирских сланцев (рис. 1) хорошо прослеживается заметная доля материала наземного происхождения (преобладание «нечетных» алканов в области $\mathrm{C}_{25}-\mathrm{C}_{35}$ ), а в содержащей наименьшее количество органического вещества породной прослойке определяющую роль играет уже бактериальная биопродукция (максимальную концентрацию имеют алканы $\mathrm{C}_{22}-\mathrm{C}_{27}$ при монотонном распределении по длине

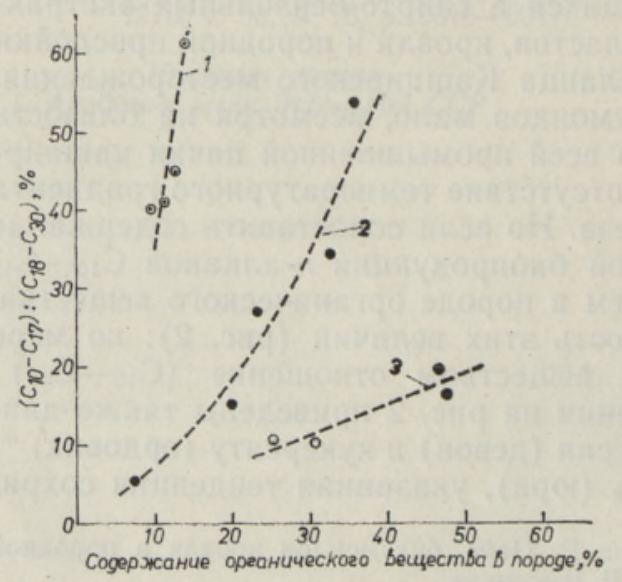
цепи). Состав жирных кислот, содержащихся в этих битумоидах, соответствует составу алканов: в породе кровли в области $\mathrm{C}_{20}-\mathrm{C}_{30}$ преобладают кислоты с четным числом атомов углерода в цепи (при декарбоксилировании превращающиеся в «нечетные» алканы),

Рис. 2. Зависимость отношения концентрации $\mathrm{H}$-алканов $\mathrm{C}_{10}-\mathrm{C}_{17} \mathrm{~K}$ конщентрации $H$-алканов $\mathrm{C}_{18}-\mathrm{C}_{30}$ в битумондах от содержания органического вещества в сланце. 1 - припятский сланец Белоруссии, 2 кашпирский сланец, 3 - кукерсит. 
в случае кислот битумоида породной прослойки этого не наблюдается.

Приведенная зависимость состава алканов битумоида от содержания в породе органического вещества проявляется при выборке образцов с близкой фациальной характеристикой, в случае малопревращенных сланцев - с преимущественно сингенетическим битумоидом. Относительное количество низших и высших парафинов неодинаково для сланцев различных бассейнов. Значительно более низкое, по сравнению с припятским и кашпирским сланцами, относительное содержание алканов до $\mathrm{C}_{17}$, свойственных первичному морскому органическому веществу, в кукерсите является, возможно, следствием аллохтонного характера основной массы его керогена. В горючих сланцах значительной степени превращенности, например, нижнеэоценовых сланцах Средней Азии, приуроченных к региону с развитыми миграционными явлениями, четкая корреляция между составом алканов и содержанием органического вещества в породе отсутствует, вероятно, вследствие маскирующего влияния вторичных битумоидов.

В свете вышесказанного при исследовании состава битумоидов горючих сланцев неверно распространять результаты, полученные для одного или части пластов, на все месторождение и недостаточно определять состав битумоида валовой пробы; вследствие изменчивости состава битумоидов для их детальной характеристики необходимо исследовать экстракты всех пластов и пропластков.

\section{ЛИТЕРАТ У РА}

1. Mathews, R. T., Cook, A. C., Johns, R. B. Relation between $n$-alkane distribution and effective coalification temperatures in some Permian shales. - Geochim. et cosmochim. acta, 1975, v. 39, N 9, p. 1237-1243.

2. Allan, J., Murchison, D., S cott, E., Wat son, S. Organic geochemistry of thermally metamorphosed fossil wood. - Fuel, 1975, v. 54, N 4, p. 283-287.

3. Johnson, R. W., Calder, J. A. Early diagenesis of fatty acids and hydrocarbons in a salt marsh environment. - Geochim. et cosmochim. acta, 1973, v. 37, N 8, p. $1943-1955$.

4. Albrecht, P., Vanderbroucke, M., M a ndelgué, M. Geochemical studies on the organic matter from the Doula Basin (Cameroon). - Geochim. et cosmochim. acta, 1976, v. 40 , N 7 , p. $791-800$.

5. Геодекян А. А., Чернова Т. Г., Ульмишек Г. Ф., Авилов В. И., Боков ой А. П., В ер хо в с к а я 3 . И., Фед доро в а М. С. Моделирование катагенетических процессов преобразования рассеянного органического вещества. Геохимия, 1977 , № 5 , с. $772-781$.

6. Купрнн П. Н., Ш лыков В. Г., Пот апов а Л. И., Мел амедова В. С. О взаимосвязи состава органического вещества и глинистых минералов в донных отложениях Каспийского моря. - В кн.: Исследования органического венества современных и ископаемых осадков. М., 1976, с. 129-135.

\footnotetext{
Ннститут химии

Академии наук Эстонской ССР
}

Поступила в редакцию 19/XII 1977 